Please cite the published version.

Shan, Yafeng. 2021. "Mendel on Developmental Information." In Information and the History of Philosophy, edited by Chris Meyns, 262-80. London: Routledge.

\title{
Mendel on developmental information
}

\section{Yafeng Shan}

\begin{abstract}
It has been widely received that one of Gregor Mendel's most important contribution to the history of genetics is his novel work on developmental information (for example, the proposal of the famous Mendelian ratios like 1:2:1, 3:1, and 9:3:3:1). This view is well evidenced by the fact that much of early Mendelians' work in the 1900s focuses on the retrodiction (i.e. the re-analysis of the pre-exist data with Mendel's approach). However, there is no consensus on what Mendel meant by development (Entwicklung). Nor is there an agreement on the interpretation of Mendel's laws of developmental series (Entwicklungsreihe). This chapter revisits Mendel's notions of development and developmental series. First, I argue that Mendel's use of development is greatly influenced by Gärtner's. Second, I show Mendel's work on developmental series are novel and important for its new ways of experimentation, conceptualisation, and analysis. Third, I argue that Mendel's laws of developmental information were not about heredity.
\end{abstract}

\section{Acknowledgements}

I would like to thank Springer for granting me permission to use the material of Chapter 1 of Doing Integrated History and Philosophy of Science: A Case Study of the Origin of Genetics (2020).

\section{Introduction}

To date, Gregor Mendel (1822-1884) is still widely credited as the father of genetics and his paper, Versuche über Pflanzen-Hybriden (1866), is viewed as the founding document of the modern study of heredity. However, the historiography of Mendel has changed dramatically for the past five decades. Mendel's paper is no longer simply viewed as an attempt to study the problem of heredity. It is now a consensus that Mendel's concern, literally speaking, is about the development of hybrids in their progeny (e.g. Müller-Wille and Orel 2007; Gliboff 2013; Zhang, Chen, and Sun 2017). It has also been widely received that one of Mendel's most important contribution to the history of genetics is his novel work on developmental series (e.g. Olby 1997; Dröscher 2015). This view is well evidenced by the fact that much of 
Please cite the published version.

Shan, Yafeng. 2021. "Mendel on Developmental Information." In Information and the History of Philosophy, edited by Chris Meyns, 262-80. London: Routledge.

early Menelians' work in the 1900s focuses on the retrodiction (i.e. the re-analysis of the pre-exist data with Mendel's approach) (e.g. Müller-Wille 2005). However, many issues on Mendel and his work remain puzzling: There is no consensus on what Mendel meant by development (e.g. Gliboff 1999; Sandler 2000). Nor is there an agreement on the interpretation of Mendel's laws of developmental series (Orel 1996, 1998; Gliboff 1999, 2013; Wood and Orel 2005; Szybalski 2010; Dijk, Weissing, and Ellis 2018). This chapter revisits three issues: What is developmental information meant by Mendel? In what sense is Mendel's conceptualisation of developmental information novel and important? Were Mendel's laws of developmental series about heredity? Section 2 explores the research context of Mendel's notion of development. Section 3 examines Mendel's notion of developmental series. Section 4 analyses the novelty of Mendel's work on developmental series. Section 5 discusses the implication of Mendel's laws of developmental series to the history of genetics.

\section{Mendel and Gärtner on development (Entwicklung)}

Mendel explicitly stated his concern in the introductory remarks (Einleitende Bemerkungen).

Artificial fertilization undertaken on ornamental plants to obtain new color variants initiated the experiments to be discussed here. The striking regularity with which the same hybrid forms always reappeared whenever fertilization between like species took place suggested further experiments whose task it was to follow the development of hybrids in their progeny.

... That no generally applicable law of the formation and development of hybrids has yet been successfully formulated can hardly astonish anyone who is acquainted with the extent of the task and who can appreciate the difficulties with which experiments of this kind have to contend. A final decision can be reached only when the results of detailed experiments from the most diverse plant families are available. Whoever surveys the work in this field will come to the conviction that among the numerous experiments not one has been carried out to an extent or in a manner that would make it possible to determine the number of different forms in which hybrid progeny appear, permit classification of these forms in each generation with certainty, and ascertain their numerical interrelationships. It requires a good deal of courage indeed to undertake such a far-reaching task; however, this seems to be the one correct way of finally reaching the solution to a question whose significance for the [developmental]i history of organic forms must not be underestimated. The paper discusses the attempt at such a detailed experiment.

(Mendel 1866, 3-4, 1966a, 1-2) 
Please cite the published version.

Shan, Yafeng. 2021. "Mendel on Developmental Information." In Information and the History of Philosophy, edited by Chris Meyns, 262-80. London: Routledge.

It seems that the problem of heredity was not Mendel's concern. Vererbung, the German word for "inheritance" or "heredity" does not appear in the introductory remarks at all. More surprisingly, it is absent in the rest of the paper, except that Mendel used the verb "vererbt (inherited)" once.ii In contrast, there are two other key words I found. The German word Hybriden (hybrids) remarkably appears 101 times. In addition, Entwicklung is another key word, appearing 45 times in the paper.iii These two key words are highly suggestive. They reflect the objective of the paper: to study "the development of hybrids in their progeny". More precisely speaking, the objective is an attempt to formulate a generally applicable law of the development of hybrids in their progeny by a detailed experiment.

The key words also suggest the research context of Mendel's work. As many historians (e.g. Olby 1979, 1985; Brannigan 1979; Müller-Wille and Orel 2007) have already argued, Mendel's work was well within the tradition of hybridism.iv This is also well corroborated by the references that Mendel made in the paper. In the paper, there are only five scholars whose works are mentioned: Kölreuter, Gärtner, Herbert, Lecoq, Wichura. Remarkably, all of them were important figures of hybridism. In Mendel's words, they all had "devoted a part of their lives to" the problem of the development of hybrids in their progeny (Mendel 1866, 3, 1966a, 1-2). What is more, in the concluding remarks (Schluss-Bemerkungen), Mendel himself clearly identifies that his work on Pisum (i.e. peas) is within the "field" of the hybridist tradition, led by "two authorities" Kölreuter and Gärtner,v and makes a lengthy comparison of his work with theirs.

\section{Table 1 Here}

Although it is now a received view that Mendel's concern was about the development of hybrids in their progeny, there is no agreement on the interpretation of Mendel's concern. Given its significance, I find it necessary to make clear the meaning of Mendel's Entwicklung at first.

In Mendel's paper, Entwicklung appears 22 times as an independent noun, and 23 times as an element in a compound word (e.g. Entwicklungsgeschichte, Entwicklungsreihe(n), and Entwicklungs-Gesetz). As a noun, it is usually translated as development, though occasionally as formation (Mendel 1966a, 33, 43) or constitution (Mendel 1965, 19, 38). Remarkably, Entwicklungsgeschichte is not accordingly translated as developmental history or the history of development. Rather it is typically translated as evolutionary history (Mendel 1966a, 2, 41) or the history of evolution (Mendel 1965, 35).vi Such a translation leads to a once popular but mistaken reading of Mendel's work and its context. For example, based on the 
Please cite the published version.

Shan, Yafeng. 2021. "Mendel on Developmental Information." In Information and the History of Philosophy, edited by Chris Meyns, 262-80. London: Routledge.

English translations of the same passage in which Entwicklungsgeschichte is translated as evolutionary history, Margaret Campbell $(1982,40)$ and L. A. Callender $(\underline{1988}, 51)$ take for granted that Mendel's work should be understood within a Darwinian evolutionary context. Such a reading is too arbitrary, however. It is problematic to conflate the 19th century German word Entwicklungsgeschichte with the 19th century English word evolution without argument. As Robert Olby (1997) points out, "it is very misleading to transpose Mendel's work from its source in the Austro-Hungarian empire to the world of Darwinian debates in Victorian England and America." Thus, in order to figure out the very meaning of Mendel's Entwicklung, it seems necessary to locate it in its intellectual context.

Sander Gliboff (1999) proposes that Mendel's use of Entwicklung was directly influenced by Franz Unger.vii For Gliboff, the connection between Unger and Mendel is both intellectual and sociological. It is recorded that Unger taught Mendel botany at University of Vienna in 1851-1853. Unger is also thought to be one of the people to whom Mendel sent an offprint of his paper.viii Both of Unger and Mendel were connected to some same academic associations (e.g. the Society of Naturalists in Brno and the Zoological-Botanical Society in Vienna) and involved in some academic activities (e.g. a project of surveying the sprawling Habsburg Empire). Thus, Gliboff $(1999,226)$ argues that under the influence of Unger, Mendel refers Entwicklung to both "the individual ontogeny and the evolution of lineage."ix

A glimpse of Unger's work seems to be compatible with Gliboff's conclusion. Entwicklung is also a key word in Unger's work, appearing 21 times in Botanische Briefe (Unger 1852a) and in 47 times in Versuch einer Geschichte der Pflanzenwelt (Unger 1852b). More surprisingly, I found that the phrases Entwicklungsgeschichte (nine times)x, Entwicklungsgesetze (once), and Entwicklungsreihe (once) were already used by Unger. Thus, it seems that Gliboff's argument that Mendel's use of Entwicklung was Unger-oriented is plausible, given the connection between Unger and Mendel. If so, another puzzle arises. If Mendel's concern was directly influenced by Unger, why was Unger not cited or mentioned at all in Mendel's paper?

A more careful reading of Unger's work (1852a, 1852b) and Mendel's paper (1866) suggests something more complicated. It is clear that Unger and Mendel used the terms Entwicklung, Entwicklungsgeschichte, Entwicklungsgesetze, and Entwicklungsreihe differently. Although both of Unger and Mendel used Entwicklung to designate individual ontogeny in some cases, Unger talked much of it at the cellular level (e.g. Unger 1852a, 104, 106, 112) while Mendel at the morphological level (Mendel 1866, 8, 11). Unger (1852a, 110) referred Entwicklungsreihe to a series of developmental process, while Mendel (1866, 5, 20, 21, 22, 24, 29, 31, 35, 39, 40) refers Entwicklungsreihe to the numerical relationships of hybrid forms. Unger's Entwicklungsgesetze (laws of development) was about the whole plant world (Unger 
Please cite the published version.

Shan, Yafeng. 2021. "Mendel on Developmental Information." In Information and the History of Philosophy, edited by Chris Meyns, 262-80. London: Routledge.

$\underline{1852 b}$, 282), while Mendel's was specifically about hybrids (Mendel 1866, 18, 32). Mendel $(1866,4)$ was explicit on the point that his work on Pisum is significant for "die Entwicklungs-Geschichte der organischen Formen (the developmental history of organic forms)", but it is too hasty to conclude that this was related to Unger's general interest of "die Entwicklungsgeschichte der Pflanzenwelt (the developmental history of plant world)", especially given that Mendel was implicit on in what sense his work would shed new light on "die Entwicklungs-Geschichte der organischen Formen." What is more, the other key word Hybriden is completely missing in Unger's work (1852a, 1852b). Therefore, it is dubious that Mendel's concern on hybrid development or his use of Entwicklung was directly influenced by Unger. In contrast, Mendel did explicitly relate his use of Entwicklung to Gärtner's both in his paper and in the correspondence to Carl Wilhelm Nägeli.

Gärtner mentions that in cases where development was regular the two parental types themselves were not represented among the offspring of the hybrids, only occasional individual closely approximating them.

(Mendel 1866, 40, 1966a, 40-41)

The results which Gärtner obtained in his experiments are known to me; I have repeated his work and have re-examined it carefully to find, if possible, an agreement with those laws of development which I found to be true for my experimental plant. (Mendel 1966b, 57)

These passages clearly show that Mendel shared the use of Entwicklung with Gärtner (at least in some cases). It seems not a big surprise, given the fact that Gärtner is the most cited scholar (18 times) in Mendel's paper. However, it is a bit surprising that nobody has yet attempted to study the meaning of Entwickelung in Gärtner's book and its influence on Mendel's use. Thus, I contend that it is worth studying Gärtner's use of Entwickelung in his book carefully for the purpose of making clear Mendel's use of Entwicklung.

Entwickelung really is one of the central terms in Gärtner's book Versuche und Beobachtungen über die Bastarderzeugung im Pflanzenreich (1849). The root word Entwicke appears 332 times in the book. In Gärtner's book, Entwickelung is definitely nothing to do with evolution (whether in a Darwinian sense or an Ungerian sensexi). Rather, it is closer to what we now refer to as individual ontogeny. In most cases,xii Gärtner designated Entwickelung to a process of the growth of the plant, or of a specific part of the plant (e.g. ovary, embryo, and flower). Here are examples.xiii 
Please cite the published version.

Shan, Yafeng. 2021. "Mendel on Developmental Information." In Information and the History of Philosophy, edited by Chris Meyns, 262-80. London: Routledge.

In contrast, in the case of natural fertilisation, although all parts of the female organs have not yet reached their full development, the pollination of the stigma with their own pollen has rarely been unsuccessful.xiv

(Gärtner 1849, 9)

If the interior of a hybrid fruit is examined in the first period of its development, the fertilised seeds are not found in the same degree of development and size.

(Gärtner 1849, 29)

These experiments seem to show once again that in addition to the various invisible developmental states of the female organs of plants, both of the sunlight and the heat ...have a great influence on the course of the fertilisation of plants.Xv

(Gärtner 1849, 49)

This doubt arises, especially in the case of hybrids: Do the defective pollen possess the power to affect the development of the outer envelopes of the fruit and the seed?xvi

(Gärtner 1849, 98)

For the four plants of this kind, which had grown from the same seed and the same pod, all the flower-heads were at the same time castrated before their development and maturity of the anthers occurred at the same time.xvii

(Gärtner 1849, 566)

It is clear that Mendel used the term Entwicklung in a similar way. For example,

A defective development of the keel has also been observed.

(Mendel 1866, 5, 1966a, 8)

In the pods first formed by a small number of plants only a few seeds developed, ...

(Mendel 1866, 13, 1966a, 11)

In addition to Entwicklung, Hybriden, the other key word in Mendel's paper, is also a central term in Gärtner's book, in which Hybriden appears 176 times and its synonym Bastarden appears 362 times. The overlap of the key words indicates a common interest: Both of Gärtner's book and Mendel's paper were about hybrids and their development, as the titles suggest.xviii Both Gärtner and Mendel talked much of laws of hybrid development, though they used the phrases slightly different. Mendel consistently spoke of Entwicklungsgesetz, while Gärtner used the phrases Entwicklungsgesetz and Gesetz der Formbildung der Bastarde interchangeably.xix What is more, Mendel's view on the law of hybrid development was very similar to Gärtner's. For instance, Gärtner strongly believed that the formation and development of hybrids were based on certain laws (die Entwickelung und Bildung einer jeden Pflanze beruhe auf gewissen Gesetzen), while those laws are still not yet known. 
Please cite the published version.

Shan, Yafeng. 2021. "Mendel on Developmental Information." In Information and the History of Philosophy, edited by Chris Meyns, 262-80. London: Routledge.

The general laws of development of the growth of the parts in hybridisation do not seem to change; all the changes in the hybrid plant-bodies follow the same laws as in the pure species.XX

(Gärtner 1849, 363)

Given original relation of plant and environment, which determines the complete development of the species, is lost, the deviation of a plant from its normal type is the necessary consequence of the development and formation of each plant which are based on certain laws, and these laws, necessary for the perfect development of a plant, are expressed in the different proportions of the external factors, light, moisture, soil, air quality, heat, etc. Yet we certainly do not know these laws; but their existence is by no means questioned, especially since they are confirmed rather by a variety of phenomena.xxi

(Gärtner 1849, 494)xxii

Rather, we hope and believe that with the help of hybridisation we will find and discover the laws of development of plants...xxiii

(Gärtner 1849, 605)

This view was also reflected by Mendel in his introductory remarks, and strengthened in several places later.

That no generally applicable law of the formation and development of hybrids has yet been successfully formulated.

(Mendel 1866, 3, 1966a, 2)

Anyone surveying the shades of color that appear in ornamental plants as a result of like fertilization cannot easily escape the conviction that ... development proceeds according to [certain laws].xxiv

(Mendel 1866, 38, 1966a, 38)

... unity in the plan of development of organic life is beyond doubt.xxv

(Mendel 1866, 43, 1966a, 43)

Mendel's conviction that a search for the law of hybrid developmentxxvi was important for the study of "the developmental history of organic forms" seems to echo Gärtner's view that the laws of hybrid development were helpful to solve the problems of species-forms and of hybrid-forms.

Since we still lack the means to explain the development of the various plant forms from the simple cell to the perfect development of the various forms of plants in their various phases to follow or construct them in the organism, we are not yet able to do 
Please cite the published version.

Shan, Yafeng. 2021. "Mendel on Developmental Information." In Information and the History of Philosophy, edited by Chris Meyns, 262-80. London: Routledge.

so to determine the correlation, with which the mechanism of hybrid development is related to the vegetable transmutation in general.xxvii

(Gärtner 1849, 293)

Doesn't the continuity and reality of a system of plants depend on the stability throughout generations? ... If the plant-species are something transitory and changeable, their development of forms is not something solid, grounded in nature, but is so much dependent on external influences that the basic form of one species changes in the course of time and may change into a completely different form. It seems to us that this vital question of systematic botany can be decided upon from the vegetation itself and from the laws of development of plants without having to wait for an answer in a millennium.xxviii

(Gärtner $\underline{1849}$, 605)

Moreover, the objective of Mendel's paper as searching for the law of the development of hybrids in their progeny seems to follow a question asked by Gärtner at the end of the book.

How do these different seeds behave in their further development (in 1849) with respect to the type of plants and their seed production?xxix (Gärtner 1849, 680)

Considering the similarity of the uses of Entwick(e)lung and the views on the law of hybrid development, and the textual connections between Mendel's and Gärtner's work, I argue that Mendel's usage of Entwicklung had been inherited from (or at least greatly influenced by) Gärtner's. In particular, as I have shown, both Mendel's and Gärtner's Entwick(e)lung were about hybrids rather than about the plant world as a whole. In other words, I argue that Mendel's usage of Entwicklung was Gärtnerianoriented rather than Ungerian-oriented.

It is worth noting that although I argue that Mendel's use of Entwicklung was inherited from Gärtner's rather than Unger's, I am not trying to dismiss Unger's influence on Mendel. I am sympathetic to the view that Mendel's work on Pisum was to some extent influenced by Unger. For example, as Gliboff (1999) and Ariane Dröscher (2015) show, Mendel's mathematical approach was indebted to Unger's quantitative approach to botany. However, I do not think that we should overestimate Unger's influence on Mendel's work. My reading of Mendel's, Gärtner's, and Unger's work show that Mendel's use of Entwicklung was much closer to Gärtner's than to Unger's. In short, there is little textual evidence to support Gliboff's reading that Mendel's use of Entwicklung was influenced by Unger.xxx Therefore, contra 
Please cite the published version.

Shan, Yafeng. 2021. "Mendel on Developmental Information." In Information and the History of Philosophy, edited by Chris Meyns, 262-80. London: Routledge.

Gliboff, I argue that Mendel's use of Entwicklung was inherited from Gärtner's rather than Unger's.

\section{Mendel's "developmental series (Entwicklungsreihe)"}

Although I argue that Mendel's use of Entwicklung was to a great extent influenced by Gärtner's, it does not imply that Mendel's concern (1866) was identical with Gärtner's (1849). Nor was Mendel's work simply a continuation of Gärtner's. Gärtner's main concern in his 1849 book was the problem of the distinction between species and accidental varieties, a central problem of hybridism. The problem originated from Linnaeus's short essay Plantae hybridae (1751), which is regarded as "the founding document of the hybridist tradition" (Müller-Wille and Orel 2007, 177). However, unlike his hybridist predecessors (e.g. Linnaeus 1751; Kölreuter 1763), Gärtner adopted a new approach. According to him,

The question of what distinguishes species from varieties is therefore ... a purely biological one: a secure foundation for determining species cannot be found solely in abstraction, neither in the characters, nor in the intermediate forms, but has to be sought in reflection, that is in the individual history (individuellen Geschichte) of each species, its whole development (Entwickelung), and not in a particular aspect only. (Gärtner 1849, 151; Müller-Wille and Orel 2007, 187)

Note that this was the first time in history to study the problem of the species/varieties distinction by examining "the development of various forms of plants (die Entwickelung der verschiedenen Pflanzenformen)" (Gärtner 1849). Thus, it provides another piece of evidence that Mendel's use of Entwicklung was influenced by

Gärtner's.

However, there is a crucial difference between Gärtner's and Mendel's concerns. Gärtner focused on the development of hybrids in one generation, while Mendel was particularly interested in the patterns of the development of hybrids in the following generations. It should be highlighted that Mendel particularly referred "the development of hybrids in their progeny" to "the developmental series" (Entwicklungsreihe) of hybrid forms in the following generations (i.e. the statistical distribution of different morphological forms). Mendel noted that the law of development of hybrid in their progeny can only be discovered by determining the "numerical relationships of different forms of hybrids". He also explicitly mentioned 
Please cite the published version.

Shan, Yafeng. 2021. "Mendel on Developmental Information." In Information and the History of Philosophy, edited by Chris Meyns, 262-80. London: Routledge.

that the numerical relationships of hybrid forms are determined by observing the developmental series of offspring.

To discover the relationships of hybrid forms to each other and to their parental types it seems necessary to observe without exception all members of the seriesxxxi (Entwicklungsreihe) of offspring in each generation.

(Mendel 1866, 5, 1966a, 4)

Thus, Mendel's concern can also be summarised as a study of the developmental series of hybrid in different generations, where the development series means the statistical information of the forms of hybrids. Accordingly, a crucial difference between Gärtner's and Mendel's work can be summarised as that Gärtner takes a qualitative approach to hybrid development, while Mendel a quantitative one. It is clear that Mendel's major discussions in the paper were centred on the developmental series.

If A denotes one of the two constant traits, for example, the dominating one, a the recessive, the Aa the hybrid form in which both are united, then the expression $\mathrm{A}+2 \mathrm{Aa}+\mathrm{a}$

gives the [developmental series] for the progeny of plants hybrid in a pair of differing traits.

(Mendel 1866, 17, 1966a, 16)

When, therefore, two kinds of differing traits are combined in hybrids, the progeny develop according to the expression:

$\mathrm{AB}+\mathrm{Ab}+\mathrm{aB}+\mathrm{ab}+2 \mathrm{ABb}+2 \mathrm{aBb}+2 \mathrm{AaB}+2 \mathrm{Aab}+4 \mathrm{AaBb}$

Indisputably this [developmental series] is a combination series in which the two [developmental series] for the traits $\mathrm{A}$ and $\mathrm{a}, \mathrm{B}$ and $\mathrm{b}$ are combined term by term. (Mendel 1866, 20-21, 1966a, 20)

The difference of forms among the progeny of hybrids, as well as the ratios in which they are observed, find an adequate explanation in the principle just deduced. The simplest case is given by the [developmental series] for one pair of differing traits. (Mendel 1866, 29, 1966a, 29)

Moreover, all Mendel's laws were in fact about the developmental series. In his paper, Mendel formulated three laws of "development of hybrid" explicitly: the law of development (Entwicklungs-Gesetz) that "apply to a pair of differing traits (welche nur in einem wesentlichen Merkmale verschieden waren)" (Mendel 1866, 18), the "law of combination of differing traits (Gesetz der Combinirung der differierenden Merkmale)" (Mendel 1866, 32), and the law of "the composition of hybrid fertilizing 
Please cite the published version.

Shan, Yafeng. 2021. "Mendel on Developmental Information." In Information and the History of Philosophy, edited by Chris Meyns, 262-80. London: Routledge.

cells (die Beschaffenheit der hybriden-Befruchtungszellen)" (Mendel 1866, 45). The law of development concerning a pair of differing traits (LDT) was formulated as follows:

[O]f the seeds formed by the hybrids with one pair of differing traits, one half again develop the hybrid form while the other half yield plants that remain constant and receive the dominating and the recessive character in equal shares.

(Mendel 1866, 17, 1966a, 15)

The law of combination of differing traits (LCT) was stated as follows.

The progeny of hybrids in which several essentially different traits are united represent the terms of a combination series in which the [developmental series] for each pair of differing are combined ... at the same time that the behavior of each pair of differing traits in a hybrid association is independent of all other differences in the two parental plants.

(Mendel 1866, 22, 1966a, 22)

The law of composition of hybrid fertilising cells (LCC) was formulated as follows.

$[\mathrm{P}]$ ea hybrids form germinal and pollen cells that in their composition correspond in equal numbers to all the constant forms resulting from the combination of traits united through fertilization.

(Mendel 1866, 29, 1966a, 29)

It is clear that Mendel's laws were all about the developmental series. For example, LDT was about the developmental series of dominating constant, hybrid, and recessive constant forms of hybrids, which was also symbolically formulated by Mendel as $\mathrm{A}+2 \mathrm{Aa}+\mathrm{a}$ where A denoted the dominating constant form, Aa the hybrid form, and a the recessive constant form.xxxii Mendel's LCT was about the developmental series in the progeny of hybrids which differs more than a pair of differing traits, while Mendel's LCC provided a reductive explanation of LCT and LCD. Thus, it seems to be more appropriate to call Mendel's laws "the laws of developmental series". This, again, confirms my argument that Mendel's concern was about developmental series in the progeny of hybrids. Therefore, I argue that when Mendel talked of the development of hybrids in their progeny, he was referring to the developmental series in the progeny of hybrids.xxxiii This is also why Mendel explicitly identified that his task is "to follow the development of hybrids in their progeny" rather than "to follow the development of 
Please cite the published version.

Shan, Yafeng. 2021. "Mendel on Developmental Information." In Information and the History of Philosophy, edited by Chris Meyns, 262-80. London: Routledge.

hybrids themselves" in the introductory remarks. That is, as I shall elaborate in more detail in the next section, Mendel was taking a quantitative approach to developmental information. Thus, Mendel's objective as looking for the law of the developmental series was definitely a creative extension of Gärtner's research. As Staffan Müller-Wille and Vitězslav Orel put it, "Mendel, in stating his aims, was simply taking the programme of Gärtner a step forward" (Müller-Wille and Orel 2007, 192). His real concern followed and developed Gärtner's interest in the development of the plant, where "the developmental history of organic forms" has been explicitly defined by Gärtner as a process from the single cell to a perfectly mature form of a plant (Gärtner 1849, 293).

\section{Mendel's novel conceptualisation: The laws of developmental series}

Some historians argue that most of Mendel's work was nothing astonishingly new. Most of his work on Pisum was merely a confirmation of observations reported before.

Before Mendel, the component parts of Mendelism had been discovered separately, some by the plant hybridizers and some by the bee breeders.

(Zirkle 1951, 103)

[Mendel's] observations on segregation and independent assortment were recorded by his predecessors and the focus on inheritance ratios was pioneered by his contemporary.

(Brannigan 1979, 440)

However, this is definitely not what Mendel himself thought of his work on Pisum. In a letter to Nägeli (dated 18 April 1867), Mendel was clear on the point that he believed that he did discover something novel or revolutionary.

I knew that the results I obtained were not easily compatible with our contemporary scientific knowledge.

(Correns 1906, 199; Mendel 1966b, 60)

Based on his carefully designed experiments, Mendel noticed the "striking regularity" of the development of hybrids in their progeny from his experiments on Pisum. For example, Mendel recognised that the hybrid seeds of purely bred yellow peas and green ones are all yellow. What is more, Mendel conceptualised the observation that 
Please cite the published version.

Shan, Yafeng. 2021. "Mendel on Developmental Information." In Information and the History of Philosophy, edited by Chris Meyns, 262-80. London: Routledge.

all the hybrids are yellow. He denoted that yellowness in the parental peas as the dominating parental trait, which referred to the parental trait passing unchanged to all of the offspring, while greenness as the recessive parental trait, which referred to the parental trait absent in the hybrid offspring.

C:IUsers\ClairelDocuments\Newgen CELMeyns\Meyns_for copyediting 19780815355007\17_CHAP15.docx - CBML_BIB_ch15_0016Table 15.2 Here

Moreover, when these hybrid seeds were self-fertilised, both yellow and green seeds were obtained in the offspring. And the ratio of the yellow seeds to the green ones was close to 3:1. Accordingly, Mendel proposed that the ratio of the seeds with the dominating trait to the ones with the recessive trait is 3:1. It must be also emphasised that it is not trivial for Mendel to recognise those Mendelian ratios. As we can see from Table 15.2, though all the ratios are close to 3:1, it was still a novel move for Mendel to make such a statistical inference.xxxiv In addition, Mendel's recognition of the 3:1 ratio was more than a simple approximation or idealisation of the raw data.

Rather it was a conceptual analysis in terms of dominance and recessiveness. Without the definition of dominating and recessive traits, the 3:1 ratio was unrecognisable. It was a substantial conceptual construction by Mendel to classify the morphological traits in terms of dominance and recessiveness. What is more, Mendel further reconceptualised the 3:1 ratio into the 1:2:1 ratio, which represented the distribution of dominating (parental), dominating (hybrid), and recessive (parental) traits.

[T] he average ratio between the number of forms with the dominating trait and those with the recessive one is ... 3:1.

The dominating trait can have double significance here - namely that of the parental characteristic or that of the hybrid trait. In which of the two meanings it appears in each individual case only the following generation can decide. As parental trait it would pass unchanged to all of the offspring; as hybrid trait, on the other hand, it would exhibit the same behavior as it did in the first generation.

(Mendel 1866, 14-15, 1966a, 13)

The ratio of 3:1 in which the distribution the distribution of the dominating and recessive traits take place in the first generation therefore resolves itself into the ratio of 2:1:1 in all experiments if one differentiates between the meaning of the dominating trait as a hybrid trait and as a parental trait.

(Mendel 1866, 16-17, 1966a, 15)

In these paragraphs, the concept of dominance was creatively redefined. Mendel distinguished two senses of the dominating trait. The dominating parental trait (or the dominating form) was the trait which passes unchanged to all of the offspring, while 
Please cite the published version.

Shan, Yafeng. 2021. "Mendel on Developmental Information." In Information and the History of Philosophy, edited by Chris Meyns, 262-80. London: Routledge.

the dominating hybrid trait (or the hybrid form) which would exhibit the same behaviour with the 3:1 ratio in its offspring, as illustrated in Figure 15.1, where A denotes the dominating parental trait, while Aa the dominating hybrid trait.

Figure 15.1 Here

This redefinition was really important for Mendel. It suggests that he recognised that there was a distinction between the yellow seeds in the F1 generation. Some yellow seeds only produced yellow seeds, while others produced both yellow and green seeds. The former was redefined as the dominating parental trait, whereas the latter as the dominating hybrid trait. This distinction led Mendel to recognise another "striking" regularity. Among the offspring of the peas with the dominating hybrid trait, the distribution of the dominating parental trait, dominating hybrid trait, and the recessive trait was 1:2:1 again. Based on this, Mendel formulated LDT, which he wished to be applicable universally. Thus, I argue that Mendel's work on developmental series was novel in three significant ways. First, Mendel designed and undertook a series of experiments, which produced massive data for his study of developmental information. Though seeking information through experimentation is not something new in hybridism, Mendel introduces a novel way of experimenting hybrids in order to study the developmental series, which is influential among the early Mendelians such as Carl Correns and Erich von Tschermak. Second, Mendel introduces new concepts (e.g. dominance, hybridness, recessiveness) to classify the data obtained from the experiments. Third, Mendel uses a new mathematical approach to analysing the developmental information.xxxv In short, as Lenny Moss (2003, 23) summarises, "Mendel's paper illustrates an exemplar for how to set up an empirical practice which makes good on the concept through the ongoing production of data." Now it is the time to highlight the significance of the Mendelian ratios. Though the phenomenon of dominance had been observed by many (e.g. Knight 1799; Goss 1824; Seton 1824) by the first half of the nineteenth century, Mendel was the first to conceptualise the phenomenon in terms of dominance/recessiveness, and record, analyse, and explain the statistical relation of dominant, hybrid, and recessive traits. Such a statistical analysis of the dominant and recessive traits was introduced into the study of heredity around 1900, especially by de Vries (1900a, 1900c, 1900d) and William Bateson (1902), which preluded the birth of genetics.

\section{Mendel and the study of heredity}

From a contemporary point of view, Mendel's laws of developmental series were obviously about transmission of hereditable traits. Thus, some historians (e.g. Orel 
Please cite the published version.

Shan, Yafeng. 2021. "Mendel on Developmental Information." In Information and the History of Philosophy, edited by Chris Meyns, 262-80. London: Routledge.

2009; Orel and Peaslee 2015; Dijk, Weissing, and Ellis 2018) argue that Mendel's laws were in fact about heredity. As Sandler $(2000,11)$ neatly summarises, Mendel's intention - 'to follow the development of hybrids in their progeny' - a stepby-step description of the transmission and distribution of hybrid traits between parent and progeny. Is it not fitting that we restore to Mendel his well-deserved title-Father of Genetics?

Such an interpretation of Mendel's work on developmental series is quite welcome, because it embraces the historiography of Mendel as a founder of genetics. There are two main lines of argument for that Mendel's laws are in fact about heredity. One is perfectly presented by Raphael Falk and Sahotra Sarkar (1991), who, though accepting that there are substantially conceptual differences between Mendel's laws and the Mendelian laws of inheritance,xxxvi argue that Mendel was studying the problem of heredity in terms of development.

Indeed, as Olby ... has observed, Mendel phrased his problem in terms of the formulation of hybrids and their progeny. The reason for this is the historical context: in the first half of the nineteenth century, Moravia was a center of intensive breeding activity which provoked considerable interest in intellectual circles ... The breeding methods of Robert Blakewell that were imported from England and promoted by Geisslern (known as the "Moravian Blakewell") were those of the production of hybrids between divergent strains showing desired traits and transmit them to the progeny over several generations. A difficulty that arose was that the traits did not breed true. When Mendel addressed such problems he was, therefore, directly addressing a problem of heredity. Conceptually, moreover, it could not have been otherwise. If hybrids are formed through reproduction, and pass traits on (with whatever success) through reproduction, and these are the traits being studied, what is being studied, ipso facto, is the inheritance of traits. The problem of inheritance is, in some sense, more general than the problem of hybridization. But that hardly means that studying hybridization is not studying inheritance.

(Falk and Sarkar 1991, 448; Linnaeus, 1751, 30)

At first glance, Falk and Sarkar's argument seems to be promising and interesting. Unfortunately, it is seriously flawed. The very problem is its anachronistic premise. Falk and Sarkar are looking at Mendel's problem with a 20th century lens. In other words, Mendel's problem was situated in a contemporary understanding of the problem of inheritance. Falk and Sarkar's argument can be reformulated as follows: $\mathrm{P} 1$. Transmission of morphological traits is a central problem in the science of heredity. 
Please cite the published version.

Shan, Yafeng. 2021. "Mendel on Developmental Information." In Information and the History of Philosophy, edited by Chris Meyns, 262-80. London: Routledge.

P2. Mendel was studying transmission of the morphological trait of Pisum in terms of development.

C. Therefore, Mendel's work was (or at least can be understood as) a study of heredity.

However, I have to warn that our current understanding of the problem of inheritance is heavily influenced by Mendel's approach. The problem of inheritance is indebted to Mendel's work. Under the influence of Mendel's focus on transmission of morphological traits, geneticists in the early 20th century began taking transmission as a central research problem in the study of heredity, which consists in our current understanding of the science of heredity. Therefore, it is anachronistic to argue that Mendel's work is about heredity by arguing that Mendel's problem is similar to the problem of transmission inheritance today!

Another line of argument for that Mendel's laws of developmental series were about heredity runs as follows: In the first half of nineteenth century there were lively discussions on heredity in Brünn, Moravia, where Mendel was undertaking his research. The interest of heredity arose from the study of sheep breeding. The term genetische Gesetze (genetic laws) was first coined in 1818 to describe the patterns of inheritance in animals by Count E. Festetics. Since 1827, the word Vererbung (heredity) had been widely used to describe the transmission of different traits. Johann Karl Nestler (1783-1841), Professor of Agriculture, Science and Natural History at the Moravian University of Olomouc, F. Diebl (1770-1859), Professor of the Philosophical Institute, and Franz Cyrill Napp (1792-1867), abbot of the Augustinian monastery in Brünn, were three key figures in the study of heredity at that time. It is argued that Mendel must have been familiar with the context, given the fact that Napp was Mendel's superior, and Mendel attended Diebl's lectures. Therefore, Mendel's work on developmental series was about heredity and "reformulated and tried to answer Napp's question 'What is inherited and how?" (Orel and Wood 2000, 1041). Orel, a strong proponent of this view, reinforces this view by arguing that a key term in Mendel's paper Entwicklungsgeschichte (the developmental history) should be identical with Verebungsgeschichte (the history of heredity).

At that time prominent sheep breeders in Moravia had kept forty years of stock registers with wool sample cards. Nestler called on them to take part in the elaboration of the principles of rational breeding to answer the key question: "What noticeable success in heredity can be achieved when rams and ewes with equal or unequal traits are paired?" The breeders were asked to examine these old family registers to investigate the history of heredity (Verebungsgeschichte) of the best stock animals in their offspring from the top downward or their developmental history (Entwicklungsgeschichte) in their ancestors from bottom upward. From this 
Please cite the published version.

Shan, Yafeng. 2021. "Mendel on Developmental Information." In Information and the History of Philosophy, edited by Chris Meyns, 262-80. London: Routledge.

investigation Nestler expected valuable material for the theory of breeding. The term Entwicklungsgeschichte was for him the other side of the same coin, of Verebungsgeschichte.

(Orel, 1998, 297; Kuhn, 1974, 464)

Emphasising the significance of his research approach from the view point of "Entwicklungsgeschichte of organic forms", Mendel could have had in mind Nestler's understanding of the history of heredity.

(Orel, 1998, 299; Gärtner, 1849, 151)

I agree with Orel that the problem of heredity was important in the context of animal breeding in Moravia. As Wood and Orel point out,

The big problem facing [breeders in Moravia] ... was the absence of a theory of inheritance. In 1836 Napp stated his opinion that the problem could be explained only by seeking its physiological basis, i.e. by discovering the nature and behaviour of whatever it was that was transmitted at fertilisation. When discussion on this topic continued in the following year, he formulated the key research question 'what is inherited and how?

(Wood and Orel 2005, 268; Gärtner, 1849, 151)

It is true that there are many discussions on Vererbung (heredity) in the literature of animal breeding in Moravia in the first half of the 19th century (e.g. Nestler 1837; Gärtner, $\underline{1849}$, 293). It is also plausible to postulate that Mendel might have known the work on Vererbung (heredity) by Nestler and Napp, through either his personal acquaintance with Napp or his study under Nestler. Nevertheless, it is still unknown to what extent Mendel was influenced by these studies on heredity: Did Mendel regard the problem of heredity as an interesting problem to study? The Sheep Breeder's Association in Brünn (SBA) was the main forum for the discussion on the problem of heredity in the first half of the 19th century. However, the sudden death of Nestler, a leader of SBA, in 1841, marks the end of activities in animal breeding somehow. As a result, the discussion on heredity in Moravia diminished. As Orel $(1977,195)$ admits, there was only occasional publication on heredity after 1840. Thus, it is very doubtful that Mendel's concern on developmental series was trying to revive an interest of heredity which was dead for at least a decade.

Given the textual evidence we have so far, it is too bold to infer that Mendel's research on the development of plant hybrids is a means to studying the problem of heredity under the influence of the Moravian sheep breeders. No direct evidence shows that Mendel's paper is related to the problem of heredity studied by Nestler and Napp. Otherwise, why didn't Mendel mention their works in the paper? Why didn't 
Please cite the published version.

Shan, Yafeng. 2021. "Mendel on Developmental Information." In Information and the History of Philosophy, edited by Chris Meyns, 262-80. London: Routledge.

Mendel even suggest the potential contribution made by his laws of developmental series to the problem of heredity? Why didn't Mendel make a comparison between his observation on peas and the work of Nestler or other breeders in the concluding remarks, as he did with Kölreuter and Gärtner?

Peter J. van Dijk, Franz J. Weissing, and T. H. Noel Ellis seem to have an answer.

Mendel's experiments had more implications, which Mendel discussed in his paper, such as the transformation of one species into another, the cytology of fertilization, the generation of variation by the conditions of life vs. hybridization, speciation, and the stability of species and hybrids. All these reflect also Mendel's interest in pure science. According to the report of the second Pisum lecture in the Mährischer Korrespondent, Mendel first gave an introduction to (what was known about) "the cell and the reproduction of the plants by fertilization." before he presented his own research (Anonymous 1865b,c). Therefore, it makes sense that Mendel chose the broad title "Experiments on Plant Hybrids," without specifically mentioning heredity or inheritance. Therefore, it makes sense that Mendel chose the broad title "Experiments on Plant Hybrids," without specifically mentioning heredity or inheritance. Mendel's broad interest in plant biology was clearly sanctioned by Napp's comments relating to the need for a scientific study of inheritance. (Dijk, Weissing, and Ellis 2018, 353)

Furthermore, a sentence in a letter written by Nägeli to Mendel is quoted as a piece of evidence that Mendel's work was about heredity.

Although the word inheritance was used only once in the text of the Pisum paper and was missing from the title, the paper is unmistakably about the rules of inheritance. That was quite clear to Nägeli when he wrote to Mendel: "I am convinced that with many forms you will get notably different results (in respect to the inherited characters [our emphasis])."

(Hoppe 1971; Dijk, Weissing, and Ellis 2018, 353)

It is correct that Mendel's paper comes across so many different topics. It is also correct that Mendel's interests were broad. However, it should be noted that not only the word Vererbung is missing, but also no discussion on heredity is found in Mendel's paper. It is definitely not "clear" that Mendel's work was about heredity. To sum up, it can be concluded that Mendel's work on developmental series was not about heredity. For those who have not yet been convinced by my arguments and are still inclined to maintain that Mendel's concern was about heredity, the puzzles remain. 
Please cite the published version.

Shan, Yafeng. 2021. "Mendel on Developmental Information." In Information and the History of Philosophy, edited by Chris Meyns, 262-80. London: Routledge.

If Mendel's real concern would have been about heredity, why didn't Mendel emphasise this literally in the paper or in his correspondence with Nägeli? Why didn't Mendel's contemporaries, especially those who were interested in the problem of heredity, read the paper as a study of heredity?xxxvii It seems to me really difficult to insist that Mendel's work is in fact about heredity until these puzzles are well solved.xxxviii

\section{Conclusion}

As many historians (e.g. Olby 1979; Orel and Wood 1998; Gliboff $\underline{1999}$; Dröscher $\underline{2015}$ ) have successfully shown, Mendel's work is not from nowhere. Mendel's work is greatly influenced by his predecessors' and contemporaries' work. So is Mendel's use of Entwicklung. In a nutshell, I argue that Mendel's use of Entwicklung was greatly influenced by Gärtner's, in which Entwicklung is defined as a process from the single cell to a perfectly mature form of a plant. (Gärtner 1849,293 ). I also argue that Mendel's real concern was to determine the developmental series of the forms of hybrids in the progeny. And I show that Mendel's work on developmental series was novel for its new ways of experimentation, conceptualisation, and analysis. Finally, I argue that Mendel's laws of developmental series were not about heredity, despite its great influence on the history of genetics.

\section{References}

Bateson, William. 1902. Mendel's Principles of Heredity: A Defence. Cambridge:

Cambridge University Press.

Brannigan, Augustine. 1979. "The Reification of Mendel." Social Studies of Science 9 (4): 423-54.

Callender, L. A. 1988. "Gregor Mendel: An Opponent of Descent with Modification." History of Science 26 (1): 41-75.

Campbell, Margaret. 1982. "Mendel's Theory: Its Context and Plausibility."

Centaurus 26: 38-69.

Correns, Carl. 1906. "Gregor Mendels Briefe an Carl Nägeli, 1866-1873."

Abhandlungen Der Mathematisch-Physischen Klasse Der Königlich Sächsischen

Gesellschaft Der Wissenschaften 29 (3): 189-265.

Dijk, Peter J. van, Franz J. Weissing, and T. H. Noel Ellis. 2018. "How Mendel's Interest in Inheritance Grew out of Plant Improvement." Genetics 210 (October): 347-55. 
Please cite the published version.

Shan, Yafeng. 2021. "Mendel on Developmental Information." In Information and the History of Philosophy, edited by Chris Meyns, 262-80. London: Routledge.

Dröscher, Adriane. 2015. "Gregor Mendel, Franz Unger, Carl Nägeli and the Magic of Numbers." History of Science 53 (4): 492-508.

Falk, Raphael and Sahotra Sarkar. 1991. "The Real Objective of Mendel's Paper: A Response to Monaghan and Corcos." Biology and Philosophy 6: 447-51.

Gärtner, Carl Friedrich. 1849. Versuche Und Beobachtungen Über Die

Bastarderzeugung Im Pflanzenreich. Stuttgart: Stuttgart.

Gliboff, Sander. 1999. "Gregor Mendel and the Laws of Evolution." History of

Science 37: 217-35.

Gliboff, Sander. 2013. “The Many Sides of Gregor Mendel.” In Outsider Scientists:

Routes to Innovation in Biology, edited by Oren Harman and Michael R. Dietrich, 2744. Chicago and London: The University of Chicago Press.

Goss, John. 1824. "On the Variation in the Colour of Peas, Occasioned by Cross Impregnation." Transactions of the Horticultural Society of London 5: 234-36.

Knight, Thomas Andrew. 1799. "An Account of Some Experiments on the Fecundation of Vegetables." Philosophical Transactions of the Royal Society of London 89: 195-204.

Kölreuter, Joseph Gottlieb. 1763. Fortsetzung Der Vorläufigen Nachricht von Einigen Das Geschlecht Der Pflanzen Betreffenden Versuchen Und Beobachtungen.

Translated by Staffan Müller-Wille and Vitězslav Orel. Leipzig.

Linnaeus, Carl. 1751. "Plantae Hybridae." In Caroli Linnaei Ammoenitates Academicae, Seu Dissertationes Variae Physicae, Medicae, Botanicae Antehac Seorsim Editae, translated by Staffan Müller-Wille and Vitězslav Orel, 3rd ed., 2862. Stockholm.

Mendel, Gregor. 1866. "Versuche Über Pflanzenhybriden.” Verhandlungen Des Naturforschenden Vereins Brünn IV (1865) (Abhandlungen): 3-47.

Mendel, Gregor. 1965. Experiments in Plant Hybridisation. Translated by Royal Horticultural Society of London. Cambridge, MA: Harvard University Press.

Mendel, Gregor. 1966a. "Experiments on Plant Hybrids." In The Origin of Genetics: A Mendel Source Book, edited by Curt Stern and Eva R. Sherwood, translated by Eva R. Sherwood, 1-48. San Francisco, CA: W. H. Freeman and Company. Mendel, Gregor. 1966b. "Gregor Mendel's Letters to Carl Nageli: 1866-1873." In The Origin of Genetics: A Mendel Source Book, edited by Curt Stern and Eva R. Sherwood, translated by Leonie Kellen Piternick and George Piternick, 56-102. San Francisco, CA: W. H. Freeman and Company.

Moss, Lenny. 2003. What Genes Can 't Do. Cambridge, MA: MIT Press.

Müller-Wille, Staffan. 2005. "Early Mendelism and the Subversion of Taxonomy: Epistemological Obstacles as Institutions." Studies in History and Philosophy of Biological and Biomedical Sciences 36 (3): 465-87. 
Please cite the published version.

Shan, Yafeng. 2021. "Mendel on Developmental Information." In Information and the History of Philosophy, edited by Chris Meyns, 262-80. London: Routledge.

Müller-Wille, Staffan, and Vitězslav Orel. 2007. "From Linnaean Species to Mendelian Factors: Elements of Hybridism, 1751-1870.” Annals of Science 64 (2): 171-215.

Nestler, J. K. 1837. "Ueber Vererbung in Der Schafzucht." Mittheilungen Der Gesellschaft Zur Beförderung Des Ackerbaues, Der Natur-Und Landeskunde in Brünn 34, 35, 36: 265-69, 273-79, 281-86, 289-93, 300-303, 318-3.

Olby, Robert Cecil. 1979. "Mendel No Mendelian?" History of Science 17 (1): 53-72. Olby, Robert Cecil. 1985. Origins of Mendelism. 2nd ed. Chicago, IL: University of Chicago Press.

Olby, Robert Cecil. 1997. "Mendel, Mendelism and Genetics." MendelWeb. 1997. www.mendelweb.org/MWolby.html.

Orel, Vitězslav. 1977. "Selection Practice and Theory of Heredity in Moravia before Mendel." Folia Mendeliana 12: 179-200.

Orel, Vitězslav. 1996. Gregor Mendel: The First Geneticist. Oxford: Oxford University Press.

Orel, Vitězslav. 1998. "Constant Hybrids in Mendel's Research." History and Philosophy of the Life Sciences 20: 291-99.

Orel, Vitězslav. 2009. “The 'Useful Questions of Heredity' before Mendel.” Journal of Heredity 100 (4): 421-23.

Orel, Vitězslav and Margaret H. Peaslee. 2015. "Mendel's Research Legacy in the Broader Historical Network." Science \& Education 24 (1-2): 9-27.

Orel, Vitězslav and Roger J. Wood. 1998. "Empirical Genetical Laws Published in Brno before Mendel Was Born." Journal of Heredity 89: 79-82.

Orel, Vitězslav and Roger J. Wood. 2000. "Essence and Origin of Mendel's

Discovery." Comptes Rendus de l'Academie Des Sciences-Serie III 323 (12): 103741.

Roberts, H. F. 1929. Plant Hybridization before Mendel. Princeton, NJ: Princeton University Press.

Sandler, Iris. 2000. "Mendel's Legacy to Genetics." Genetics 154 (1): 7-11.

Seton, A. 1824. "Note by the Secretary." Transactions of the Horticultural Society of London 5: 236-37.

Shan, Yafeng. 2020a. “Kuhn's 'Wrong Turning 'and Legacy Today.” Synthese 197 (1): 381-406.

Shan, Yafeng. 2020b. Doing Integrated History and Philosophy of Science: A Case Study of the Origin of Genetics. 1st ed. Boston Studies in the Philosophy and History of Science. Cham: Springer.

Szybalski, W. 2010. "Professor Alexander Zawadzki of Lvov University-Gregor Mendel's Mentor and Inspirer." Biopolymers and Cell 26 (2): 83-86.

Unger, Franz. 1852a. Botanische Briefe. Vienna: Verlag von Carl Gerold \& Sohn. 
Please cite the published version.

Shan, Yafeng. 2021. "Mendel on Developmental Information." In Information and the History of Philosophy, edited by Chris Meyns, 262-80. London: Routledge.

Unger, Franz. 1852b. Versuch Einer Geschichte Der Pflanzenwelt. Vienna: Wilhelm Braumüller.

Vries, Hugo de. 1897. "Erfelijke Monstrositeiten in Den Ruilhandel Der Botanische Tuinen.” Botanisch Jaarboek 4: 62-93.

Vries, Hugo de. 1900a. "Das Spaltungsgesetz Der Bastarde (Vorlaufige

Mittheilung)." Berichte Der Deutschen Botanischen Gesellschaft 18 (3): 83-90.

Vries, Hugo de. 1900b. "Hybridising of Monstrosities." Journal of the Royal Horticultural Society 24: 69-75.

Vries, Hugo de. 1900c. "Sur La Loi de Disjonction Des Hybrides." Comptes Rendus de I'Academie Des Sciences (Paris) 130: 845-47.

Vries, Hugo de. 1900d. "Sur Les Unités Des Caractères Spécifiques et Leur Application à l'étude Des Hybrides." Revue Générate de Botanique 12: 257-71. Wood, Roger J., and Vitězslav Orel. 2005. "Scientific Breeding in Central Europe during the Early Nineteenth Century: Background to Mendel's Later Work." Journal of the History of Biology 38: 239-72.

Zhang, Hui, Wen Chen, and Kun Sun. 2017. "Mendelism: New Insights from Gregor Mendel's Lectures in Brno." Genetics 207 (September): 1-8.

Zirkle, Conway. 1951. "Gregor Mendel \& His Precursors.” Isis 42 (2): 97-104.

Figure 15.1 Illustration of the behaviour of a dominating parental trait (denoted by A) and a dominating hybrid trait (denoted by $\mathrm{Aa}$ )

Table 15.1 Cited Scholars in Mendel's paper (1866)

\begin{tabular}{|l|l|}
\hline Cited scholar & Number of occurrences \\
\hline Kölreuter & 6 \\
\hline Gärtner & 18 \\
\hline Herbert & 1 \\
\hline Lecocq & 1 \\
\hline Wichura & 3 \\
\hline
\end{tabular}

Table 15.2 The Result of the First Generation of the Hybrid Acquired by Mendel (Mendel 1866)

\begin{tabular}{|l|l|l|l|}
\hline Experiment & $\begin{array}{l}\text { Number (of seeds } \\
\text { with one trait) }\end{array}$ & $\begin{array}{l}\text { Number (of seeds with } \\
\text { the other trait) }\end{array}$ & Ratio \\
\hline
\end{tabular}


Please cite the published version.

Shan, Yafeng. 2021. "Mendel on Developmental Information.” In Information and the History of Philosophy, edited by Chris Meyns, 262-80. London: Routledge.

\begin{tabular}{|l|l|l|l|}
\hline 1 & 5474 (round) & 1850 (wrinkled) & $2.96: 1$ \\
\hline 2 & 6022 (yellow) & 2001 (green) & $3.01: 1$ \\
\hline 3 & 705 (grey-brown) & 224 (white) & $3.15: 1$ \\
\hline 4 & 882 (inflated) & 299 (constricted) & $2.95: 1$ \\
\hline 5 & 428 (green) & 152 (yellow) & $2.82: 1$ \\
\hline 6 & 651 (axial) & 207 (terminal) & $3.14: 1$ \\
\hline 7 & 787 (long) & 277 (short) & $2.84: 1$ \\
\hline
\end{tabular}

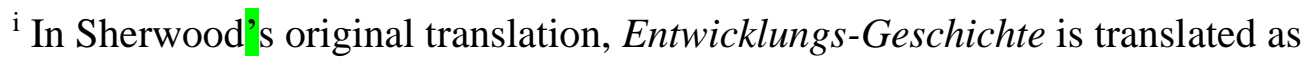
“evolutionary history". However, I prefer to my translation as “developmental history", given the contemporary usage of "evolution".

ii The original German text is "auch beschränkt sich diese Eigentümlichkeit nur auf das Individuum und vererbt sich niche auf die Nachkommen". (Mendel 1866, 14) (Eva R. Sherwood's translation (1966a, 12): “furthermore, this peculiarity is restricted to the individual and not inherited by the offspring.")

iii It should be noted that Entwicklung is also a key word in Mendel's correspondence to Nägeli, appearing 19 times, either as an independent noun or as an element of a compound word. 
Please cite the published version.

Shan, Yafeng. 2021. "Mendel on Developmental Information." In Information and the History of Philosophy, edited by Chris Meyns, 262-80. London: Routledge.

${ }^{\text {iv }}$ Hybridism is a research tradition, focusing on the study of plant hybrids by crossing experiments, in the late $18^{\text {th }}$ and early $19^{\text {th }}$ century. The central problem of hybridism is what distinguishes species from accidental varieties. The leading figures of hybridism include Carl Linnaeus (1707-1778), Joseph Gottlieb Kölreuter (1733-1806), and Carl Friedrich von Gärtner (1772-1850). For a detailed study of the history of hybridism, see Roberts (1929), Olby (1985), and Müller-Wille and Orel (2007).

A comparison of the observations made on Pisum with the experimental results obtained by Kölreuter and Gärtner, the two authorities in this field, cannot fail to be of interest." (Mendel 1966a, 39)

vi The recent BSHS translation by Staffan Müller-Wille and Kirsten Hall (http://www.bshs.org.uk/bshs-translations/mendel/2016?page=1\&sentence=1) corrects this.

vii Unger (1800-1870) was an Austrian botanist, notable for his pre-Darwinian theory of evolution (1852b).

viii Gliboff $(\underline{1999}, 234 \mathrm{f} 33)$ admits that there is some doubt about this, though.

${ }^{\text {ix }}$ Individual ontogeny is the development of an organism, usually a process from the fertilisation of the egg to the organism's mature form. 
Please cite the published version.

Shan, Yafeng. 2021. "Mendel on Developmental Information." In Information and the History of Philosophy, edited by Chris Meyns, 262-80. London: Routledge.

"This shows that Gliboff"s claim $(1999,235 \mathrm{f} 42)$ that the term "Entwicklungsreihe" seems to be Mendel's own coinage is problematic.

${ }^{x i}$ When talking of the Ungerian evolution, I have Unger's concept of Entwicklungsgeschichte in mind. Unger (1852a, 1852b) speaks much of Entwicklungsgeschichte, which, as Gliboff $(\underline{1999}, 226)$ correctly points out, refers to changes in the flora through the geological time.

${ }^{\text {xii }}$ For an exhaustive list of Gärtner's usage of Entwickelung in his book (1849), see Appendix 5.

xiii Gärtner's book (1849) is not yet translated into English. If not indicated otherwise, all the translations of Gärtner's text are mine.

xiv “..., da im Gegentheil bei der natürlichen Befruchtung, wenn auch alle Theile der weiblichen

Organe ihre vollstandige Entwickelung noch nicht erlangt haben, eine Bestäubung der Narbe mit dem eigenen Pollen sehr selten erfolglos bleibt,..."

xv "Diese Versuche scheinen abermals zu zeigen, dass neben den verschiedenen, dem Auge 
Please cite the published version.

Shan, Yafeng. 2021. "Mendel on Developmental Information." In Information and the History of Philosophy, edited by Chris Meyns, 262-80. London: Routledge.

unsichtbaren Entwickelungsgraden der weiblichen Organe der Gewächse, die beide Agentien, das

Sonnenlicht und die Wärme, (s. oben S. 10) einen grossen Einfluss auf den Gang der Befruchtung der Pflanzen haben." xvi "Hier tritt namentlich bei den Hybriden der Zweifel ein: ob nicht auch der taube Pollen die Kraft besitze, die Entwickelung der äusseren Umhüllungen der Frucht und der Samen zu bewirken."

xvii “An vier Pflanzen dieser Art, welche aus dem gleichen Samen aus einer und derselben Schote

aufgegangen waren, wurden alle Blumenknöpfe vor ihrer Entwickelung und eingetretenen Reife der Antheren zu gleicher Zeit castrirt."

${ }^{\text {xviii }}$ Recall the title of Mendel's paper is "Experiments on Plant Hybrids", while the title of Gärtner's book is “Experiments and Observations on Hybrid Formation in the Plant Kingdom."

${ }^{\text {xix }}$ Gärtner sometimes used the phrases Entwickelung and Bildung interchangeably (e.g. Gärtner $\underline{1849}, 585)$. 
Please cite the published version.

Shan, Yafeng. 2021. "Mendel on Developmental Information." In Information and the History of Philosophy, edited by Chris Meyns, 262-80. London: Routledge.

xx "Die allgemeinen Entwickelungsgesetze der Theile der Gewächse scheinen daher durch

diehybride Zeugung keine, den Sinnen perceptible Aenderung zu erfahren; sondern alle Entwickelungen und Veranderungen des hybriden Pflanzenkorpers nach denselben Gesetzen zu erfolgen, wie bei den reinen Arten."

xxi “Werde dieses ursprüngliche, die vollständige Entwickelung, ja die Existenz der Art bedingende, Verhältniss aufgehoben, so sei die Abweichung einer Pflanze von ihrem Normaltypus die nothwendige Folge davon, d. i. die Entwickelung und Bildung einer jeden Pflanze beruhe auf gewissen Gesetzen, und werde durch diese bedingt, und diese Gesetze sprechen sich aus in den, zur vollkommenen Entwickelung einer Pflanze nothigen, verschiedenen Verhaltnissen der Einwirkung der ausseren Momente, Licht, Feuchtigkeit, Boden, Luftbeschaffenheit, Wärme u. s. w. Noch kennen wir freilich diese Gesetze so gut als gar nicht; ihr Vorhandensein lasse sich aber durchausnicht mehr verkennen, wir seien vielmehr durch eine Menge von Erscheinungen gezwungen, sie als vorhanden anzunehmen."

xxii This is a quote from Hornschuh, but it is clear that Gärtner shared this view. 
Please cite the published version.

Shan, Yafeng. 2021. "Mendel on Developmental Information." In Information and the History of Philosophy, edited by Chris Meyns, 262-80. London: Routledge.

xxiii “"wir hoffen und glauben vielmehr, dass wir mit Hulfe der Bastardzeugung zur Auffindung und Entdeckung der Formgesetze der Gewächse gelangen werden."

xxiv Sherwood's original translation is that "according to a certain law", but it is in fact a mistranslation, because in Mendel's German text the plural form Gesetze (laws) is used.

xxv “... die Einheit im Entwicklungsplane des organischen Lebens ausser Frage steht.” ${ }^{x x v i}$ Mendel never explicitly defined Gesetz (law), but he contended that a law should be something universally applicable and studied empirically.

xxvii "Da es uns noch an Mitteln fehlt, die Entstehung und Entwickelung der verschiedenen Pflanzenformen von der einfachen Zelle an bis zur vollendeten Entwickelung des vollkommenen Gewächses in ihren verschiedenen Phasen zu erklärren und im Organismus zu verfolgen oder zu construiren: so sind wir auch noch nicht im Stande, die Bande zu bestimmen, womit der Metaschematismus der hybriden Bildung mit der vegetabilischen Metamorphose überhaupt zusammenhängt."”

xxviii “'Beruht dann nicht die Dauer und Wirklichkeit eines Systems der Gewä̈chse auf der Stabilitat in der Art von Generation zu Generation? Würde das Streben und die Arbeit der Systematiker aller Zeiten und die kostbaren Iconographien nicht zur blosen Spielerei herabsinken und völlig unnutz sein? wenn die 
Please cite the published version.

Shan, Yafeng. 2021. "Mendel on Developmental Information." In Information and the History of Philosophy, edited by Chris Meyns, 262-80. London: Routledge.

Pflanzenart etwas Vergangliches und Wandelbares, ihre Gestaltsbildung nicht etwas Festes, in der innersten Natur Begründetes, sondern von äusseren Einwirkungen soweit Abhangiges ware, dass die Grundform einer Art im Laufe der Zeiten sich andern, in eine ganz andere Gestalt übergehen, und in ein ganz anderes Wesen sich verwandeln würde.

Es scheint uns, dass diese Lebensfrage der systematischen Botanik aus der Vegetation selbst und aus den Gesetzen der Formbildung der Gewächse werde entschieden werden konnen, ohne auf die Entscheidung von Jahrtausenden warten zu mussen."

xxix "Wie sich diese verschiedenen Samen in ihrer weiteren Entwickelung (im Jahr 1849) in Absicht auf den Typus der Pflanzen und ihrer Samenerzeugung verhalten werden."

${ }^{\mathrm{xxx}}$ For a similar reason, I find Iris Sandler's claim $(2000,9)$ that Mendel's use of Entwicklung is influenced by M. J. Schleiden untenable. Sandler's reason is that "as a botanist [Mendel] would have been familiar with the textbook written by the leading botanist of the period, M. J. Schleiden... Its influence was widespread." To me, such a speculation is too bold. 
Please cite the published version.

Shan, Yafeng. 2021. "Mendel on Developmental Information." In Information and the History of Philosophy, edited by Chris Meyns, 262-80. London: Routledge.

xxxi This is a major error in Sherwood's translation (Mendel 1966a), in which Entwicklungsreihe is translated as series rather than developmental series in all of its 17 occurrances. Clearly, such a translation fails to reflect the significance of Entwicklungsreihe (or even Entwicklung) in Mendel's paper (1866).

${ }^{\text {xxxii }}$ For an elaboration of this, see section 4.

xxxiii Unfortunately, partly because of the traditional mistranslation of Entwicklungsreihe (Bateson 1902; Mendel 1966a), historians used to overlook the relation of "developmental series (Entwicklungsreihe)" and "the development of hybrids in their progeny (die Entwicklung der Hybriden in ihren Nachkommen)".

xxxiv Three decades later, Hugo de Vries, when undertaking the similar crossing experiments, initially failed to recognise the 3: 1 ratio. Based on the results of his crossing experiments on Lychnis vespertina glabra $\times$ Lynchnis diurnal in 1894, de Vries $(\underline{1897}, 72)$ claimed that the ratio of the hairy seedlings and hairless seedling is 2:1. However, three years later, de Vries $(\underline{1900 \mathrm{~b}}, 75)$ modified it as a 3:1 ratio. 
Please cite the published version.

Shan, Yafeng. 2021. "Mendel on Developmental Information." In Information and the History of Philosophy, edited by Chris Meyns, 262-80. London: Routledge.

${ }^{\mathrm{xxxv}}$ Note that by arguing that Mendel's mathematical approach is novel, I do not mean to argue that Mendel was the first to use the mathematical or statistical approach to biological study. As Dröscher (2015) shows, mathematical thinking was not as alien as thought in the $19^{\text {th }}$ century biology. I argue that Mendel was creative for introducing the mathematical approach to the problem of hybrid development in two senses. Firstly, Mendel's mathematical approach was different from his contemporaries' like Unger’s or Nägeli’s. Secondly, Mendel was the first to use a mathematical approach to developmental information. Although both Gärtner and Mendel focus on hybrid development, Gärtner was taking a qualitative approach, while Mendel a quantitative one.

xxxvi Mendel's laws are what are articulated in Mendel's paper, while the Mendelian laws of inheritance are what are developed by the early Mendelians (e.g. William Bateson) and classical geneticists (e.g. T. H. Morgan). There are some obvious difference between Mendel's laws and the Mendelian laws. For example, the Mendelian laws are typically formulated in terms of genes, while Mendel did not have a concept of gene. For a detailed discussion, see Robert Olby $(\underline{1979}, \underline{1985})$. 
Please cite the published version.

Shan, Yafeng. 2021. "Mendel on Developmental Information." In Information and the History of Philosophy, edited by Chris Meyns, 262-80. London: Routledge.

${ }^{\text {xxxvii }}$ Recent studies on the reports of Mendel's lecture in 1865 by local newspaper (Zhang, Chen, and Sun 2017; Dijk, Weissing, and Ellis 2018) confirm my scepticism. None of the five articles read Mendel's work as a study of heredity.

xxxviii It should be noted that I am not trying to dismiss the significance of Mendel's work in the history of genetics. I am happy with the historiography of Mendel as a founder of genetics, but resist the interpretation that Mendel was interested in heredity or Mendel's work was about heredity. For my interpretation, see Shan (2020a, 2020b). 